\title{
27. LOWER CRETACEOUS LITHOSTRATIGRAPHY OF THE CONTINENTAL RISE OFF THE WESTERN SAHARA
}

\author{
V. A. Basov, B. G. Lopatin, I. S. Gramberg, A. I. Danyushevskaya, V. Ya. Kaban'kov, V. M. Lazurkin, \\ and D. K. Patrunov, Research Institute of the Geology of the Arctic, Scientific Technical Complex \\ SEVMOREGO, Leningrad, USSR
}

\section{INTRODUCTION}

The Lower Cretaceous deposits that were penetrated in Hole $397 \mathrm{~A}$ at a depth of 1296.7 to 1453.0 meters just below the lower Miocene deposits are in many respects enigmatic. The onboard study of core material resulted in contradictions as to the depositional environment, paleodepth of water, genesis of thin carbonate layers, and nature of diagenetic changes.

Our work provides a lithologic-mineralogic study (X-ray analysis of clay and carbonate), microfauna determinations, and geochemistry analysis of the clay and organic matter of these Lower Cretaceous deposits. Its purpose is to examine their environmental setting and the nature of diagenetic changes. Unfortunately, limited core material (52 samples, each from 20 to 30 grams) and lack of time allowed only preliminary results to be obtained.

The contributors to this paper are: V. Ya. Kaban'kov, B. G. Lopatin, and D. K. Patrunov (lithology and mineralogy); V. M. Lazurkin (clay minerals); V. A. Basov (biostratigraphy); I. S. Gramberg (geochemistry of clays); and A. I. Danyushevskaya (geochemistry of organic matter). The conclusions were written jointly and this paper was edited by B. G. Lopatin.

\section{LITHOLOGY AND MINERALOGY}

The Lower Cretaceous deposits are homogeneous in composition, and it is difficult to divide them into lithologic units. They consist of dense dark gray silty clay with thin layers of lighter clayey siltstone and yellowgray dense clay with carbonate material. In the shipboard report, the yellow-gray layers were described as microgranular dolomite; however, detailed study showed that they are complexly constituted and siderite predominates the carbonate fraction. Coarsegrained sediments are represented only by several sandy siltstone beds in Core 397A-39.

The whole sequence is thin-bedded and varve-like in Cores 397A-40 to 43 and 45 to 49 . Variations in amount of silty material are responsible for their thinbedded character. Burrows are scarce and do not disturb the bedding. Slump structures occur at the base of the sequence (Cores 397A-50 and 51). Dips throughout this sequence range between 10 and 30 degrees, averaging about 20 degrees.

Grain size and mineralogy of these sediments were studied from 11 typical samples (Tables 1 and 2, Fig- ure 1). Grain size of the fraction smaller than $0.01 \mathrm{~mm}$ was determined by the pipette method (water analysis); for coarser fractions, sieving was used. Initial ultrasonic treatment was used for disintegration of aggregates. We used a sodium pyrophosphate solution $\left(\mathrm{Na}_{4} \mathrm{P}_{2} \mathrm{O}_{7}\right)$ as a dispergator. The mineral composition of the terrigenous material was determined mainly by the immersion method of the 0.1 to $0.05 \mathrm{~mm}$ fraction. Additionally, the rocks were studied in thin sections.

All the analyzed samples are silty clays. X-ray quantitative analysis of the clay minerals showed a uniform composition (Table 3 ). The clay minerals consist of illite (55 to $65 \%$ ), kaolinite ( 15 to $20 \%$ ), chlorite ( $10 \%$ ), montmorillonite (5 to $10 \%$ ), and mixed-layered mineral ( 5 to $10 \%)$.

In thin sections, aggregates of brown greenish oriented illite flakes dominate with intercalations of almost colorless illite. Authigenic silica is usually confined to the colorless illite aggregates. Silt-size and some sand-size clastic material, which is persistent within the clayey matrix, is represented mainly by quartz and feldspar (Table 2, Figure 1). Quartz fragments are usually angular or angular-rounded, transparent, and smooth surfaced. They are corroded when cemented by calcite.

Feldspars are mainly sodic plagioclase, tabular, and fresh. Intermediate and calcic plagioclases are common but not abundant. Potash feldspars are usually pelitized.

An association of heavy minerals is persistent throughout the section (Table 1). Garnet, zircon, and leucoxene are rounded or angular-rounded. Tourmaline, anatase, and brookite are well rounded or occur as well-developed crystals, implying a different origin. Hornblends occur as fresh elongate-prismatic grains and as well-rounded clastic mica with flakes usually parallel to bedding. Muscovite dominates with subordinate biotite and chlorite. Fe-carbonate and opaques often coat the biotite and chlorite laths. Biotite is sometimes replaced by hydromicas. In addition, organic detritus is common in the clastic material including black and brownish black plant tissue and cuticle fragments of 0.1 to $0.2 \mathrm{~mm}$, seldom to $1 \mathrm{~mm}$ (Appendix B).

The rocks contain an admixture of carbonate material, partly resulting from the recrystallization of nannofossils and partly of diagenetic origin. Carbonates are scattered as small aggregates and form concentrations in lens-like bands up to $2 \mathrm{~mm}$ thick, which are related to layers of light clays of hydromica composition. 
TABLE 1

Summary of Hole 397A Light Fraction Analysis, 0.1 to $0.05 \mathrm{~mm}$

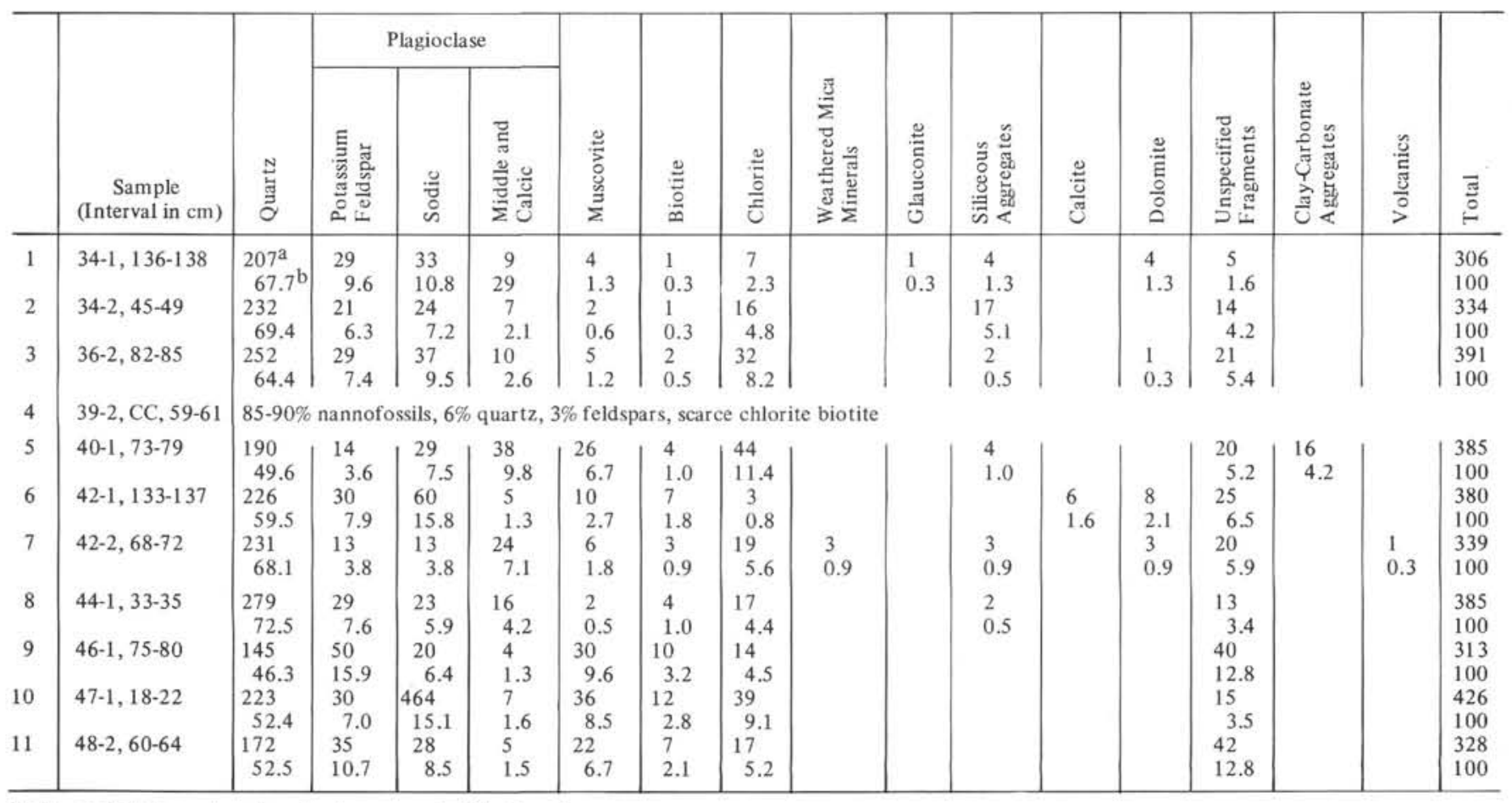

Note: $\mathrm{a}=$ Total number of grains, $\mathrm{b}=$ per cent of total grains.

TABLE 2

Summary of Hole 397A Heavy Fraction Analysis, 0.1 to $0.05 \mathrm{~mm}$

\begin{tabular}{|c|c|c|c|c|c|c|c|c|c|c|c|c|c|c|c|}
\hline $\begin{array}{c}\text { Sample } \\
\text { (Interval in } \mathrm{cm} \text { ) }\end{array}$ & 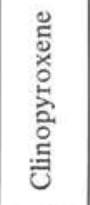 & 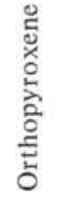 & 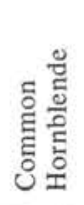 & 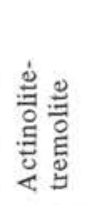 & 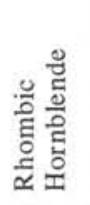 & 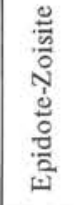 & 芯 & 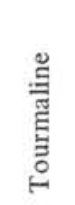 & $\begin{array}{l}\overleftarrow{\Xi} \\
\stackrel{\Xi}{\sharp}\end{array}$ & $\begin{array}{l}\text { 동 } \\
\text { 点 }\end{array}$ & $\begin{array}{l}\frac{\mathscr{D}}{5} \\
\frac{5}{2} \\
\text { के }\end{array}$ & 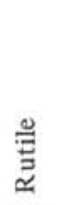 & 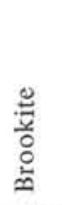 & 默 & 咅嵒 \\
\hline $\begin{array}{l}34-1,136-138 \\
34-2,45-49 \\
36-2,82-85\end{array}$ & $\begin{array}{l}4^{\mathrm{a}} \\
0.7^{\mathrm{b}} \\
2 \\
0.2\end{array}$ & & $\begin{array}{l}12 \\
2.1 \\
13 \\
1.6 \\
9 \\
2.4\end{array}$ & $\begin{array}{l}1 \\
0.2\end{array}$ & $\begin{array}{l}2 \\
0.5\end{array}$ & \begin{tabular}{|l}
2 \\
0.3 \\
5 \\
0.6 \\
11 \\
3.0
\end{tabular} & $\begin{array}{c}28 \\
4.9 \\
24 \\
2.9 \\
30 \\
8.1\end{array}$ & $\begin{array}{l}20 \\
3.5 \\
19 \\
2.3 \\
10 \\
2.7\end{array}$ & $\begin{array}{c}17 \\
3.0 \\
32 \\
3.9 \\
21 \\
5.8\end{array}$ & $\begin{array}{c}25 \\
4.3 \\
31 \\
3.7 \\
16 \\
4.3\end{array}$ & $\begin{array}{l}1 \\
0.2 \\
3 \\
0.4 \\
9 \\
2.4\end{array}$ & $\begin{array}{l}1 \\
0.2 \\
4 \\
0.5 \\
5 \\
1.3\end{array}$ & $\begin{array}{l}3 \\
0.5 \\
4 \\
0.5 \\
1 \\
0.3\end{array}$ & $\begin{array}{l}3 \\
0.4\end{array}$ & $\begin{array}{c}18 \\
3.1 \\
22 \\
2.6 \\
13 \\
3.5\end{array}$ \\
\hline $39-2, \mathrm{CC}, 59-61$ & The fr: & tion & hists er & irely of & yrite & & & & & & & & & & \\
\hline $40-1,73-79$ & $\begin{array}{l}12 \\
45 \% \text { py }\end{array}$ & $\begin{array}{l}1 \\
\text { cite, }\end{array}$ & $\begin{array}{c}4 \\
\mathrm{Fe}-\mathrm{Car}\end{array}$ & onate a & gregates & 122 & 28 & 13 & 32 & 14 & 7 & 1 & 1 & 1 & 8 \\
\hline
\end{tabular}

Note: $a=$ Total number of grains, $b=$ per cent of total grains; analysis by V. A. Aleinikova, A. I. Savinova, E. A. Popova, and L. K. Turjetskaya, Research Institute of the Geology of the Arctic, Leningrad. 
Petrographic study shows that the carbonates consist of tiny rhombohedral crystals 1 to $5 \mu \mathrm{m}$ and nannoplankton remains. In places, carbonate is recrystallized into mosaic grains from 0.1 to $0.15 \mathrm{~mm}$ in size. We noted in Sample 397A-42-1, 133-137 cm that part of the nannofossils consist of dolomite.

According to thermobalance analysis (UTA-1) of four yellow clay-carbonate samples taken at different intervals (Figure 2), siderite is the predominant carbonate mineral (to $60 \%$ ) and Fe-dolomite makes up about 3 to 4 per cent. Refractive indexes of rhombohedral grains range from 1.704 to 1.712 , which corresponds to ferric dolomite.

Siltstone and fine-grained silty sandstones occur in subordinate thin bands. Their composition was studied in thin sections. Clastic material, which forms twothirds of the rock, is mainly quartz (60 to $70 \%$ ) and feldspar (15 to $20 \%$ ). These grains are angular and angular-rounded. Mica and chlorite fragments do not exceed 10 per cent. Sodic plagioclase predominates among feldspars; potassium feldspar is common.

Among micas in the silty clay, muscovite predominates. Biotite is strongly altered into hydromica, chlorite, and ferric carbonates. Therefore, we presume that the amount of biotite was higher before diagenesis.

The cement of siltstone and sandstone differs in type and composition. Well-crystallized calcite matrix of poikieitic type prevails. Calcite mosaic grains are $1 \mathrm{~mm}$ in size. Calcite aggregates replace primary clay, porous matrix, and partially replace clastic minerals. Preserved parts of the primary matrix consists of hydromica and fine ferrous hydroxide films on quartz grains. The heavy mineral assemblage is the same as that of the silty clays.

The clastic rocks always contain small amounts of pyrite resulting mainly from organic matter in the form of fine dispersed dust.

\section{BIOSTRATIGRAPHY}

The Lower Cretaceous sediments in Hole 397A yielded benthic and planktonic foraminifers, radiolarians, and ostracodes.

Foraminifers are generally of very small size and low diversity, which makes an age determination difficult.

About 35 species belonging to 26 genera and 11 families were determined (Table 4). Most genera are represented by one or two species; only Lenticulina are more variable. Species as a rule are represented by single specimens found in a limited number of samples. Only Pseudosigmoilina ex gr. infravalanginiana Bart. is abundant almost in all fossiliferous samples (Figure 5). Planktonic foraminifers of small "Globigerina" type and benthic large Lenticulina are abundant in Sample 397A-40-4, 30-33 cm. Hoeglundina though scarce, occurs persistently. Agglutinated foraminifers are not as abundant as secretionary types, although ferric casts and strongly deformed shells probably belonging to

TABLE 2 - Continued

\begin{tabular}{|c|c|c|c|c|c|c|c|c|c|c|c|c|c|c|c|c|}
\hline 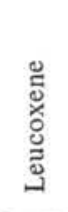 & $\begin{array}{l}\text { 苛 } \\
\text { 苞 } \\
\text { ผ }\end{array}$ & 营 & 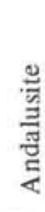 & $\begin{array}{l}\frac{}{0} \\
\frac{0}{0} \\
\text { d }\end{array}$ & 苛 & : & 䒕 & 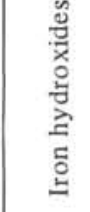 & $\begin{array}{l}\tilde{\Xi} \\
\tilde{\Xi} \\
\tilde{0}\end{array}$ & $\stackrel{\Xi}{\Xi}$ & 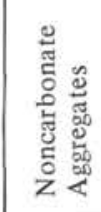 & $\frac{\mathscr{U}}{\frac{0}{3}}$ & 冚 & 营 & స్ & 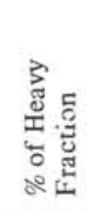 \\
\hline $\begin{array}{c}42 \\
7.3 \\
68 \\
8.2 \\
30 \\
8.1\end{array}$ & $\begin{array}{l}1 \\
0.2 \\
1 \\
0.2\end{array}$ & $\begin{array}{l}1 \\
0.3\end{array}$ & & $\begin{array}{l}7 \\
1.2 \\
5 \\
0.6 \\
2 \\
0.5\end{array}$ & $\begin{array}{l}1 \\
0.2 \\
5 \\
0.6 \\
8 \\
2.2\end{array}$ & $\begin{array}{c}20 \\
3.5 \\
14 \\
1.7 \\
70 \\
19.0\end{array}$ & $\begin{array}{l}2 \\
0.3\end{array}$ & $\begin{array}{c}43 \\
7.6 \\
13 \\
1.6 \\
10 \\
2.7\end{array}$ & $\begin{array}{c}82 \\
14.2 \\
227 \\
27.0 \\
71 \\
19.3\end{array}$ & \begin{tabular}{|c}
52 \\
9.1 \\
8 \\
1.0 \\
50 \\
13.6
\end{tabular} & $\begin{array}{c}187 \\
32.5 \\
327 \\
39.2\end{array}$ & $\begin{array}{l}6 \\
1.0 \\
2 \\
0.2 \\
1 \\
0.3\end{array}$ & 0.1 & & $\begin{array}{l}574 \\
100 \\
832 \\
100 \\
370 \\
100\end{array}$ & $\begin{array}{c}0.45 \\
21 \\
0.50 \\
0.82\end{array}$ \\
\hline 7 & & & & 5 & 1 & 21 & & & | 11 & & & & & 1 & 190 & 22.44 \\
\hline $\begin{array}{l}20 \\
1.5\end{array}$ & $\begin{array}{l}1 \\
0.1\end{array}$ & & & $\begin{array}{l}2 \\
0.1\end{array}$ & $\begin{array}{l}45 \\
3.3\end{array}$ & $\begin{array}{c}13 \\
0.9\end{array}$ & & & $\begin{array}{l}16 \\
1.2\end{array}$ & & & & & & $\begin{array}{l}206 \\
100\end{array}$ & .08 \\
\hline $\begin{array}{c}46 \\
8.6 \\
78 \\
13.1 \\
55 \\
9.2 \\
17 \\
2.2 \\
29 \\
6.0\end{array}$ & $\begin{array}{l}1 \\
0.2 \\
1 \\
0.2 \\
1 \\
0.2 \\
2 \\
0.3\end{array}$ & & & $\begin{array}{l}9 \\
1.7 \\
7 \\
1.2 \\
3 \\
0.5 \\
1 \\
0.1 \\
3 \\
0.6\end{array}$ & $\begin{array}{c}7 \\
1.3 \\
13 \\
2.2 \\
37 \\
6.2 \\
28 \\
3.7 \\
38 \\
7.7\end{array}$ & $\begin{array}{c}178 \\
33.3 \\
59 \\
9.9 \\
105 \\
17.5 \\
2 \\
0.3 \\
67 \\
13.6\end{array}$ & & $\begin{array}{c}40 \\
6.6 \\
250 \\
33.2 \\
33 \\
6.7\end{array}$ & \begin{tabular}{|c}
95 \\
17.7 \\
150 \\
25.4 \\
88 \\
14.6 \\
20 \\
2.6 \\
105 \\
21.3
\end{tabular} & \begin{tabular}{|c}
5 \\
0.9 \\
37 \\
6.2 \\
27 \\
4.5 \\
350 \\
46.5 \\
13 \\
2.6
\end{tabular} & $\begin{array}{c}43 \\
7.2 \\
20 \\
2.6 \\
56 \\
10.8\end{array}$ & & $\begin{array}{l}2 \\
0.3\end{array}$ & & $\begin{array}{l}535 \\
100 \\
593 \\
100 \\
600 \\
100 \\
753 \\
100 \\
492 \\
100\end{array}$ & $\begin{array}{l}2.27 \\
0.33 \\
35 \\
25 \\
43\end{array}$ \\
\hline
\end{tabular}




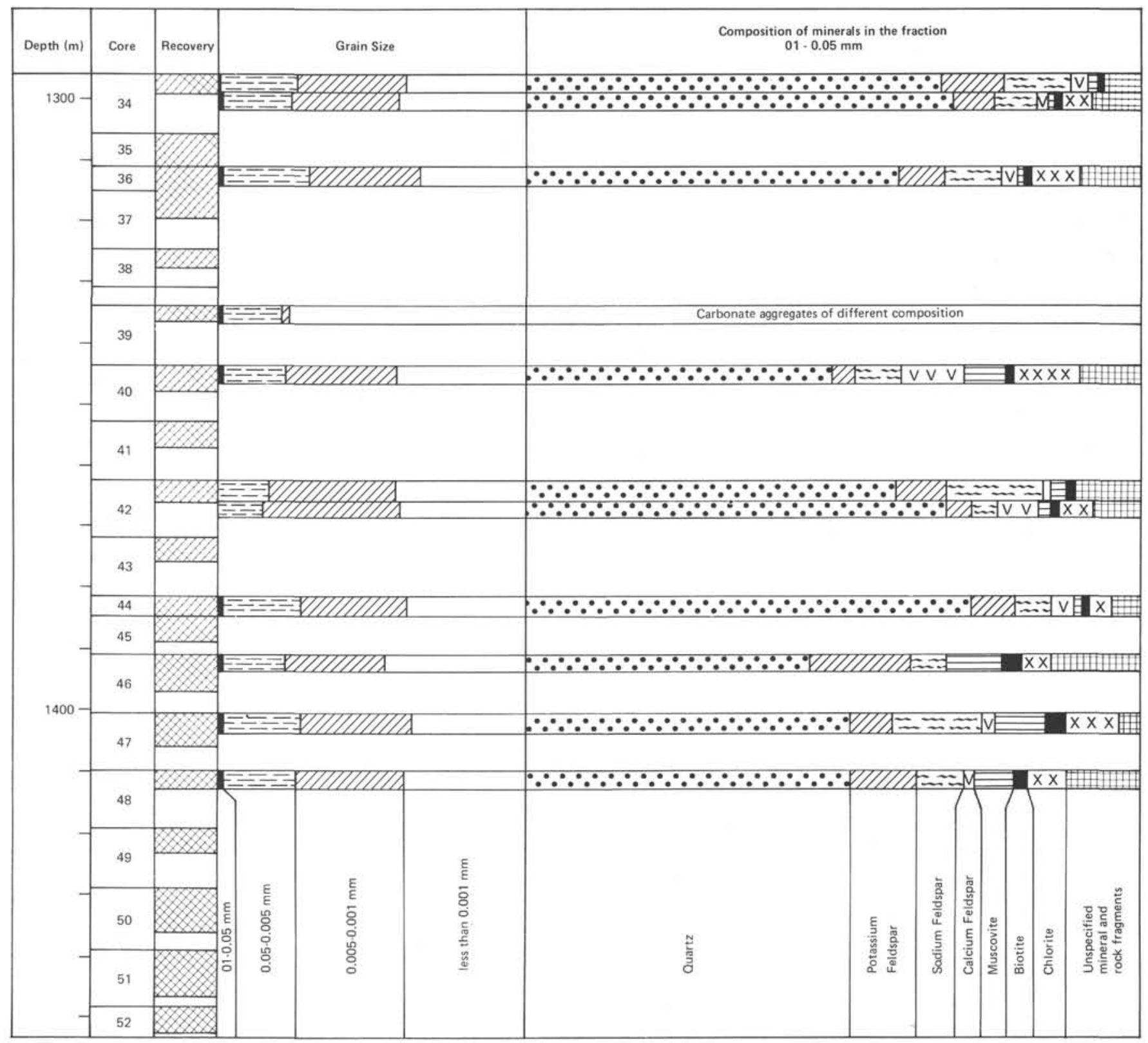

Figure 1. Grain size and mineral composition analysis of 11 samples from Hole $397 \mathrm{~A}$ (each horizontal bar corresponds to one sample).

Saccamminidae(?) and Astrorhizidae(?) are common in some samples.

Radiolarians are also scarce and occur only sporadically in several samples. Two valves of ostracodes in Sample 397A-50-1, 37-41 cm were determined by P. S. Lyubimova as Bythocytheromorpha and Paijenborehella.

We note some difference between microfossil assemblages in the lower and upper parts of the section. In Cores 397 A-46 to 50 (1392 to $1436 \mathrm{~m}$ ), foraminifers are variable. Different Lenticulina, planktonic foraminifers as "Globigerina" triangulata Antonova and Blowiella blowi (Bolli) were found only in this interval.

In the upper part of the section (above Core 397A-46), the microfauna is poorer and of lower diversity. We found Hedbergella(?) sp. and radiolarians here as well. However, their differences are not sufficient to establish any age differences. We can provide age correlations of the sequence studied only in broad temporal terms. The identified foraminifer assemblage possibly correlates to Lower Cretaceous faunas of the North Caucasus and Alps (Antonova et al., 1964; Fuchs, 1971). A number of species is common with those from the upper Barremianlower Aptian of the North Caucasus, such as benthic Hoeglundina laticostata (Antonova), $\mathrm{H}$. aff. umboornata (Antonova), Pseudolamarckina? ex gr. lamplughi (Sherlock), Quinqueloculina horrida Antonova; Lenticulina nodosa (Reuss) and planktonic "Globigerina" triangulata Antonova, "Globigerina"” aff. tardita Antonova. 
TABLE 3

Composition of Hole 397A Clay Minerals, wt. \%

\begin{tabular}{|c|c|c|c|c|c|}
\hline $\begin{array}{c}\text { Sample } \\
\text { (Interval in } \mathrm{cm} \text { ) }\end{array}$ & $\stackrel{\Xi}{\Xi}$ & $\frac{\stackrel{\Xi}{5}}{\frac{0}{2}}$ & 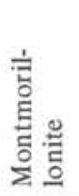 & 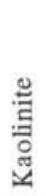 & 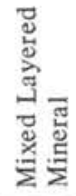 \\
\hline $34-1,136-138$ & 60 & 10 & - & 20 & 10 \\
\hline $34-2,45-49$ & 60 & 10 & 5 & 20 & 5 \\
\hline $36-2,82-85$ & 60 & 10 & 5 & 20 & 5 \\
\hline $42-1,133-137$ & 60 & 10 & 5 & 15 & 10 \\
\hline $42-2,68-72$ & 55 & 10 & 10 & 20 & 5 \\
\hline $44-1,33$ & 60 & 10 & 5 & 15 & 10 \\
\hline $46-1,75-80$ & 65 & 10 & 5 & 15 & 5 \\
\hline $47-1,18-22$ & 60 & 10 & 10 & 15 & 5 \\
\hline $48-2,60-64$ & 55 & 10 & 10 & 15 & 10 \\
\hline
\end{tabular}

Note: X-ray analyses on diffractometer DRON-1 conducted by V. N. Gerasimov, Research Institute of the Geology of the Arctic, Leningrad.

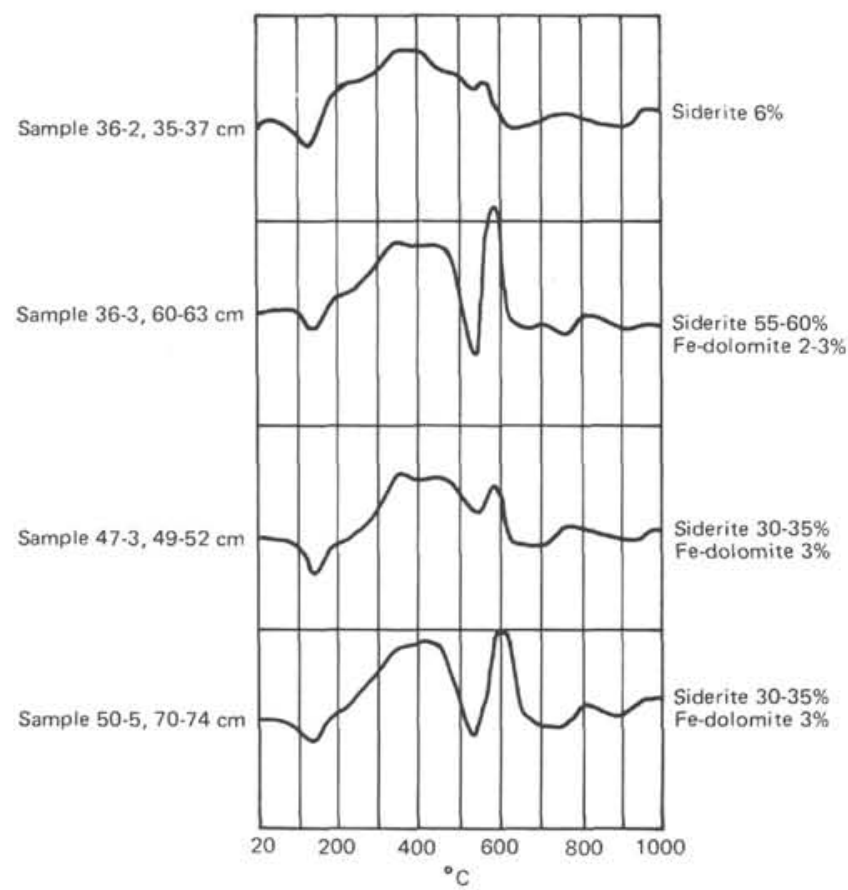

Figure 2. Thermograms of the carbonate-bearing samples from Hole $397 A$.

Some planktonic foraminifers close to Clavihedbergella simplex (Morrow) and Schackoina trifolia Fuchs bear apparent similarity with the Alpine forms described by Fuchs from the missle Barremian of western Austria (Fuchs, 1971).

Finally, Lenticulina sp. 2 and L. roemeri Reuss found in our samples were reported from the middleupper Barremian of Trinidad (Bartenstein et al., 1957).

Certainly we cannot consider this slight similarity to the known Barremian and lower Aptian fossils as being of significance. It is more important that a comparison with older Berriasian-Valanginian and Hauterivian fossils of the Tethys and epicontinental basin of Europe suggests even less similarity. First of all, pre-Barremian planktonic fauna are never as variable as that which we found in Section 397A-47-4. Hoglundins are similar but still different. Some forms of nodosariids (except for Lenticulina sp. 2 Bart., Bett., and Bolli and Planularia bradyana Chapman) show a certain similarity to species occurring in older parts of Lower Cretaceous deposits. Pseudosigmoilina ex gr. infravalaginiana Bart., which predominate in the sequence, has not been reported from deposits younger than Valanginian.

In addition, we found Miocene foraminifers at the top of the sequence (Sample 397A-34-2, 45-59 cm) such as Plectofrondicularia sp., Hoeglundina sp., Bolivina sp., Ammonia sp., Stilostomella sp., and representatives of Globigerinidae. This obviously is due to contamination from overlying Miocene sediments.

We think that the most probable age of the sequence is Barremian or Barremian-early Aptian. This conclusion is better substantiated for the upper part of the section, above Core 397A-47. For the lowermost part of the section, a Hauterivian age cannot be excluded.

\section{GEOCHEMISTRY OF CLAYS}

Seven samples of silty clays partly grouped from several samples (Tables 5 and 6 ) were studied geochemically.

A technique developed at the Institute of the Geology of the Arctic was used for the analysis of absorbed cations. For extraction of absorbed cations, the sample was soaked in $\mathrm{NH}_{4} \mathrm{Cl}$ solution for one day (the ratio of rock to solution was 1:5) after we had washed the rock in 60 per cent alcohol solution to eliminate readily soluble salts.

The absorbed complex of the samples studied has a high potassium content ( 10 to $23 \%$ ) and relatively high content of alkaline-earth elements ( 37 to $60 \%$ ) where magnesium predominates. The comparison of absorbed complexes for Sections 397A-37-3, 39-1, 41-1, 41-2, 46-3, and 46-4 indicates an environment close to normal marine; Sections 397A-34-2, 43-1, 43-2, and 49-1 are indicative of freshening water conditions.

For the analysis of hard soluble components, we used vinegar acid extract with addition of reducer (i.e., sodium metabisulfate) to prevent the destruction of alumosilicates. These components are mainly hydroxides with high iron content. Among alkaline-earth oxides, calcium predominates. Sections $397 \mathrm{~A}-46-3$ and 46-4 have a high calcium and sulfur content, perhaps implying enrichment in gypsum.

\section{GEOCHEMISTRY OF DISPERSED ORGANIC MATTER (DOM)}

We conducted extensive chemical and physicochemical studies determine the genesis and diagenetic transformations of DOM (Tables 7, 8, and 9; Figures 3 and 4). Besides the study of DOM, we determined the distribution of iron cations in enclosing rocks. This enabled us, using the method proposed by Strakhov and Zalmanzon (1955), to evaluate depositional environments and degree of anaerobic losses of DOM during 
TABLE 4

Distribution of Foraminifers in Hole 397A

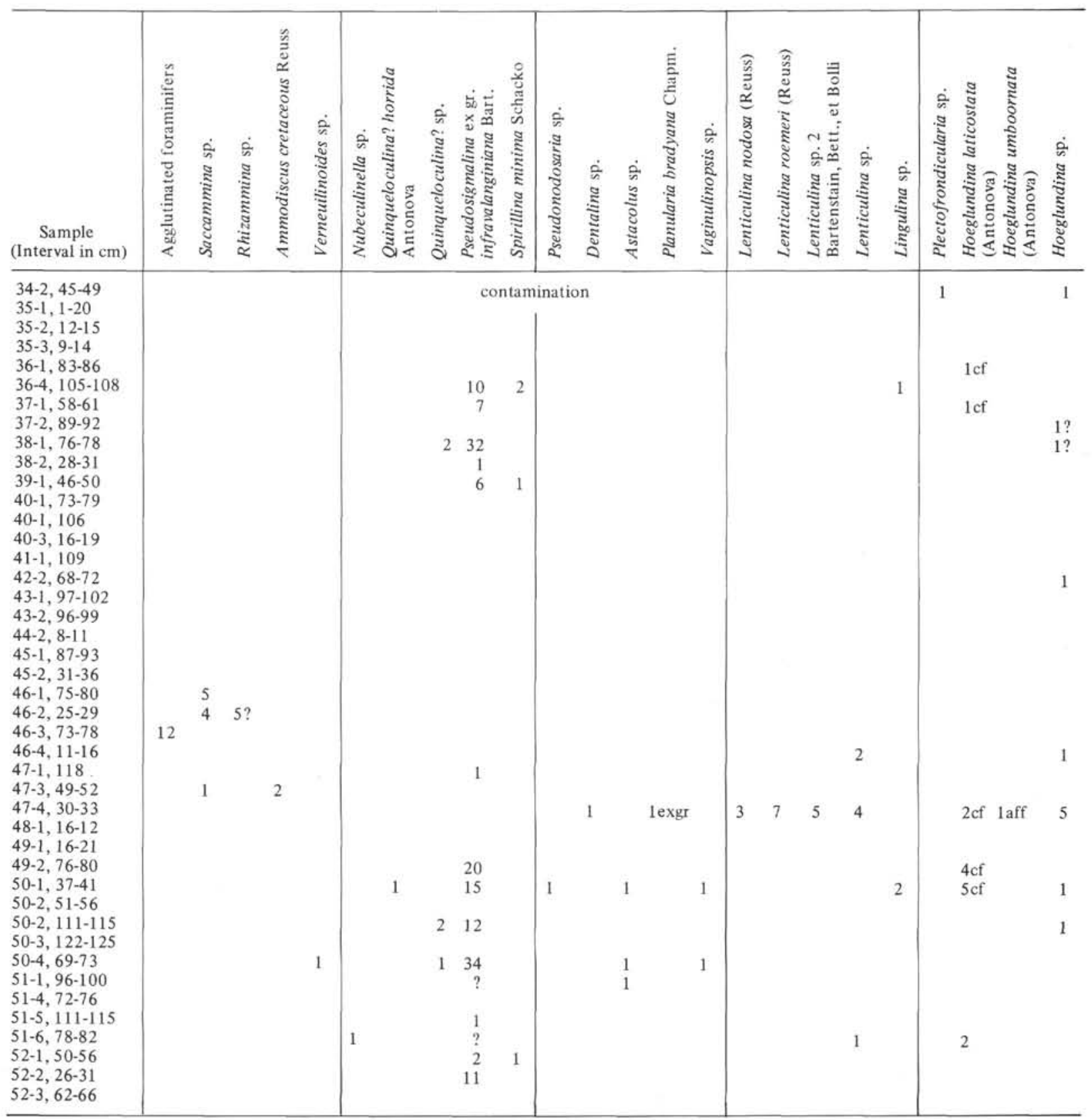

diagenesis (Table 9). Appendix A gives a short description of the method used.

The distribution of DOM was determined using luminiscence and microscopic analyses (Appendix B).

To obtain representative samples (about $100 \mathrm{~g}$ each), we grouped seven and eight samples into two groups of composite samples. Composite Sample 7 includes: Samples 397A-35-1, 120-126 cm; 35-2, 12-15 $\mathrm{cm}$; 35-3, 9-14 cm; 36-1, 83-86 cm; 37-1, 58-61 cm; $37-2,89-92 \mathrm{~cm}$; and $38-2,28-31 \mathrm{~cm}$. Composite Sample 8 consists of Samples $397 \mathrm{~A}-50-1,37-41 \mathrm{~cm} ; 50-3$; $122-125 \mathrm{~cm} ; 50-4,69-73 \mathrm{~cm} ; 51-1,96-100 \mathrm{~cm} ; 51-4$, $72-76 \mathrm{~cm}$; $51-6,78-82 \mathrm{~cm}$; $52-1,50-56 \mathrm{~cm}$; and $52-2$, $26-30 \mathrm{~cm}$. All the samples are silty clays; Sample 7 rep- resents the 1310 to 1330 -meter interval and Sample 8 represents the 1440 to 1453 -meter interval.

The results of luminiscence and microscopic analyses show that DOM in the studied rocks is a dispersed mass forming a single organo-mineral assemblage with clay minerals. Numerous black fusainized inclusions of detritus randomly scattered in rocks, as well as fragments of cuticles and other plant tissues, are indicative of the importance of DOM clastic material formed by higher plants. A level of carbonification transformations of DOM (using refractive indexes of vitrinite inclusions) reaches a brown coal stage $\left(\mathrm{B}_{3}\right)$. A transformation of DOM into organic-mineral mass, as well as fusainization of detritus material, implies possible oxi- 
TABLE 4 - Continued

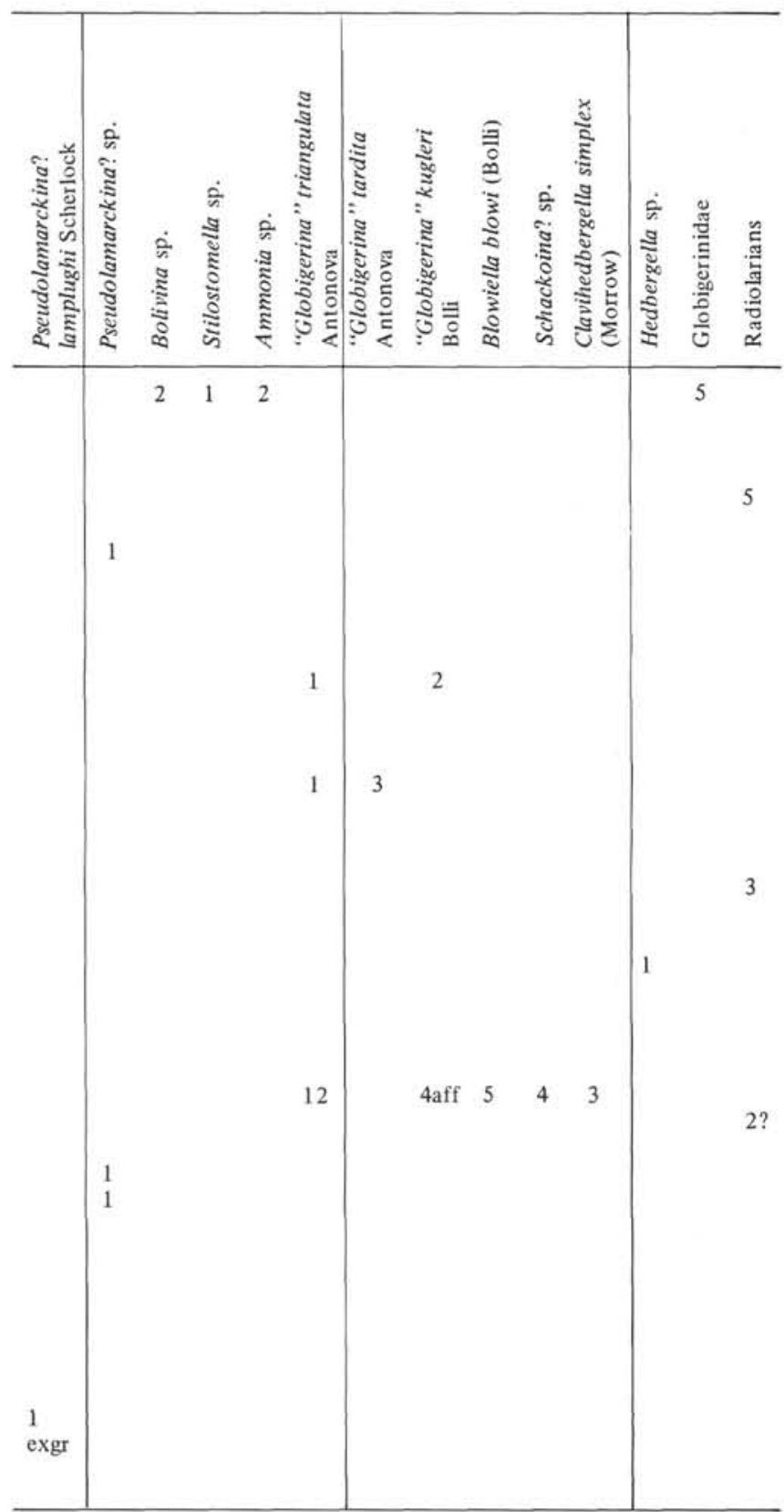

dizing transformations of DOM. Oxidizing conditions are proved by the high proportion of ferric oxides in the sediments (Table 9).

The data obtained show that anaerobic diagenetic discharge of organic carbon for a transformation of $\mathrm{Fe}^{+++}$into $\mathrm{Fe}^{+++}$is not high and accounts for 3 to 4 per cent as compared to the primary discharge. Oxidizing transformation of organic material is shown by intense humification and a high percentage of humic acids in the DOM group content.

A similarity in bitumoid distribution of "closed" and "open" pores (Table 8) suggests diagenetic generation of hydrocarbons, which replenishes "closed" pores and detach into "open" ones. Luminescent microscopic data confirm the presence of migrative light hydrocarbons of white-blue luminescence in pore space (Appendix B). The differences between elementary and group composition of bitumoids of "closed" and "open" pores and high carbon and oil content of the "open" ones also prove a diagenetic generation of hydrocarbons. Lower total abundances of hydrocarbons and their methane-naphthene fraction in Samples 7 and 8 (Table 10 ) suggest that the intensity of new formation is low and almost unchangeable in this interval (1310 to $1453 \mathrm{~m}$ ).

A genetic similarity of primary organic matter is shown by the similarity of infrared absorption spectra of bitumoids of "open" and "closed" pores (Figure 3 ). The presence of naphthalene, phenanthrene, and hrizene aromatic structures supports a considerable role of higher plants in primary organic matter production. We noted the presence of 5-nucleus aromatic perilene and fluoranthene as an indicator of the terrigenous primary origin of the organic matter.

Interpretation of the differences in $n$-alkanes trends in accordance with bitumoid fractions of "open" and "closed" pores (Figure 4) is open to discussion. Undoubtedly, the $n$-alkanes trend follows primary lipid compositional peculiarities. Thus, long chain $n$-alkanes $\mathrm{C}_{23}-\mathrm{C}_{35}$ dominating among hydrocarbons recovered from "open" pores are also indicative of terrigenousderived material, higher plants being a source material.

We consider the predominance of $\mathrm{C}_{18}-\mathrm{C}_{24}$ in "closed" pores as resulting from newely built DOM components at an early stage of destruction.

This organic matter apparently is a source of $\mathrm{CH}_{4}$ and trace amounts of $\mathrm{C}_{2}-\mathrm{C}_{5}$ found at depths from 850 to 1450 meters.

Thus, DOM in the Lower Cretaceous deposits at depths of 1310 to 1453 meters is of mixed genesis and formed mainly from plant remains and, to a lesser degree, hydrobionts. At the stage discussed, transformation conditions of DOM are oxidizing. DOM has passed the whole cycle of diagenetic change and reached the brown coal stage $\left(B_{3}\right)$ of carbonification. An initial phase of katagene transformations of DOM fixed at this stage leads to the production of gaseous hydrocarbons (mainly methane) and, to a lessor degree, of light fluid hydrocarbons. The concentration of humic acids in DOM suggests that oxidizing transformations seem to have followed the melanoiodine trend (Manskaya and Drozdova, 1964). The transformation trends of initial organic material can be confirmed only when we finish the study of humic acids, amino acid composition of organic matter and kerogen.

\section{CONCLUSIONS}

The data obtained enable us to conclude that the depositional environment during Early Cretaceous time differed from present-day normal marine conditions and, on the whole, was unfavorable for life activity. The conditions were unstable and subject to periodic changes.

Foraminifers, both planktonic and benthic, are of small size and low diversity. A slight flourish of a lenti- 
TABLE 5

Composition of Absorbed Cations in Samples From Hole 397A

\begin{tabular}{|c|c|c|c|c|c|c|c|c|c|c|c|c|c|c|c|c|c|c|c|c|}
\hline \multirow[b]{3}{*}{$\begin{array}{c}\text { Sample } \\
\text { (Interval in cm) }\end{array}$} & \multicolumn{12}{|c|}{ Composition of $\mathrm{NH}_{4} \mathrm{Cl}$ Extract } & \multirow{3}{*}{ 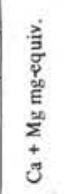 } & \multirow{3}{*}{ 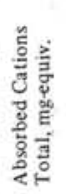 } & \multicolumn{3}{|c|}{ \% Equivalent } & \multirow{3}{*}{ 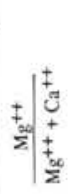 } & \multirow[b]{3}{*}{$\frac{\mathrm{Na}^{+}}{\mathrm{K}^{+}}$} & \multirow{3}{*}{ 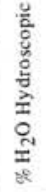 } \\
\hline & \multicolumn{2}{|c|}{$\mathrm{Na}^{+}$} & \multicolumn{2}{|c|}{$\mathrm{K}^{+}$} & \multicolumn{2}{|c|}{$\mathrm{Mg}^{++}$} & \multicolumn{2}{|c|}{$\mathrm{Ca}^{++}$} & \multicolumn{2}{|c|}{$\mathrm{HCO}_{3}^{+}$} & \multicolumn{2}{|c|}{$\mathrm{SO}_{4}^{++}$} & & & & & & & & \\
\hline & $\xi$ & $\begin{array}{l}\text { 咅 } \\
\text { है }\end{array}$ & $\%$ & 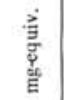 & $\%$ & 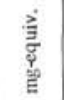 & $\%$ & 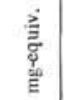 & $\%$ & 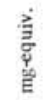 & $\%$ & 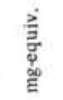 & & & $\mathrm{Na}^{+}$ & $\mathrm{K}^{+}$ & $\begin{array}{c}+ \\
\pm \\
+\infty \\
\frac{\infty}{2}\end{array}$ & & & \\
\hline $34-2, \mathrm{CC}$ & 0.080 & 3.48 & 0.095 & 2.43 & 0.057 & 4.65 & 0.110 & 5.50 & 0.225 & 3.69 & 0.016 & 0.38 & 6.13 & 12.04 & 28.90 & 20.18 & 50.92 & 0.76 & 1.4 & 5.17 \\
\hline $\begin{array}{l}37-3,116-120 \\
38-1,76-80 \\
39-1,46-50\end{array}$ & 0.128 & 5.57 & 0.103 & 2.64 & 0.045 & 3.72 & 0.110 & 5.50 & 0.190 & 3.11 & 0.023 & 0.48 & 5.63 & 13.84 & 40.25 & 19.08 & 40.67 & 0.66 & 2.1 & 2.17 \\
\hline $40-3,16-19$ & 0.104 & 4.52 & 0.118 & 3.02 & 0.039 & 3.17 & 0.112 & 5.60 & 0.191 & 3.13 & 0.017 & 0.35 & 5.29 & 12.83 & 35.23 & 23.54 & 41.23 & 0.60 & 1.5 & 4.18 \\
\hline $\begin{array}{l}41-1,109-114 \\
41-2,98-100\end{array}$ & 0.130 & 5.65 & 0.086 & 2.20 & 0.047 & 3.89 & 0.118 & 5.91 & 0.190 & 3.11 & 0.032 & 0.67 & 6.02 & 13.87 & 40.74 & 15.86 & 43.40 & 0.65 & 2.6 & 4.42 \\
\hline $\begin{array}{l}48-1,97-102 \\
48-2,96-99\end{array}$ & 0.140 & 6.09 & 0.088 & 2.25 & 0.120 & 9.84 & 0.122 & 6.09 & 0.173 & 2.84 & 0.017 & 0.35 & 12.74 & 21.08 & 28.89 & 10.67 & 60.44 & 0.77 & 2.7 & 9.32 \\
\hline $\begin{array}{l}46-3,73-78 \\
46-4,11-16\end{array}$ & 0.126 & 5.48 & 0.072 & 1.84 & 0.034 & 2.78 & 0.192 & 9.57 & 0.171 & 2.80 & 0.251 & 5.23 & 4.32 & 11.64 & 47.08 & 15.81 & 37.11 & 0.64 & 3.0 & 5.86 \\
\hline $49-1,16-21$ & 0.122 & 5.30 & 0.114 & 2.92 & 0.077 & 6.36 & 0.131 & 6.55 & 0.204 & 3.34 & 0.031 & 0.65 & 8.92 & 17.14 & 30.92 & 17.04 & 52.04 & 0.71 & 1.8 & 4.60 \\
\hline
\end{tabular}

Note: Analysis by A.F. Zelenova, Research Institute of the Geology of the Arctic, Leningrad,

culine assemblage and planktonic foraminifers (judging from abundant fossils in Cores 46 and 47) suggests a temporary change to normal marine environment.

The dwarfed microfauna may be accounted for by stagnant basin conditions and salinity fluctuations towards fresher water. The strongest freshening based on geochemistry data is characteristic of Sections 397A$42-2,43-1,43-2$, and 49-1. Foraminifers were not found in these intervals.

In our opinion, the benthic fauna is typical of a population in a partly closed basin having a limited exchange of water (i.e., of a stagnant basin type). In par- ticular, the fauna at this site is similar to some Recent populations of foraminifers in shelf troughs.

The absence of burrowing may be explained by oxygen-depleted conditions near the sea bottom, cool water, or a shortage of food.

We think sedimentation of thin ferriferous carbonate bands in association with light clays took place when the basin was most stagnant. Ferriferous carbonate suggests reducing conditions in sediment at a relatively high $\mathrm{CO}_{2}$ partial pressure, i.e., a condition of carbon dioxide poisoning in a reducing zone. Such an environment is obviously characteristic of a freshened basin

TABLE 6

Composition of Hard Soluble Components

\begin{tabular}{|c|c|c|c|c|c|c|c|c|c|c|c|c|c|c|}
\hline \multirow[b]{2}{*}{$\begin{array}{c}\text { Sample } \\
\text { (Interval in } \mathrm{cm} \text { ) }\end{array}$} & \multicolumn{12}{|c|}{ Dry Rock (\%) } & \multicolumn{2}{|c|}{ mmole } \\
\hline & 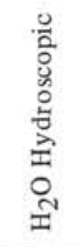 & 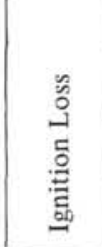 & 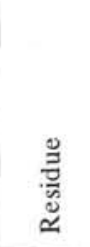 & กั & ల్ల & $\stackrel{\aleph}{N}_{k}^{m}$ & E & ర్ల & $\sum_{\sum}^{\infty}$ & @ & 8 & 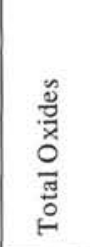 & กั & 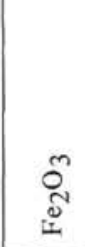 \\
\hline $34-2, \mathrm{CC}$ & 5.17 & 7.43 & 91.32 & 0.57 & 3.64 & 0.40 & 0.076 & 0.75 & 0.38 & 0.06 & 0.97 & 6.85 & 9.42 & 22.79 \\
\hline $\begin{array}{l}37-3,116-120 \\
38-1,76-80 \\
39-1,46-50\end{array}$ & 2.17 & 5.90 & 93.84 & 0.66 & 1.85 & 0.67 & 0.045 & 0.57 & 0.16 & 0.12 & 0.62 & 4.70 & 10.98 & 11.58 \\
\hline $40-3,16-19$ & 4.18 & 6.07 & 92.95 & 0.63 & 2.52 & 0.61 & 0.050 & 0.43 & 0.23 & 0.10 & 0.62 & 5.19 & 10.48 & 15.78 \\
\hline $\begin{array}{l}41-1,109-114 \\
41-2,98-100\end{array}$ & 4.42 & 8.53 & 90.68 & 0.56 & 3.14 & 0.42 & 0.051 & 1.35 & 0.35 & 0.13 & 1.44 & 7.44 & 9.32 & 19.66 \\
\hline $\begin{array}{l}43-1,97-102 \\
43-2,96-99\end{array}$ & 9.32 & 6.44 & 94.75 & 0.57 & 1.49 & 0.49 & 0.035 & 0.47 & 0.14 & 0.10 & 0.52 & 3.82 & 9.49 & 9.33 \\
\hline $\begin{array}{l}46-3,73-78 \\
46-4,11-16\end{array}$ & 5.86 & 10.79 & 85.83 & 0.48 & 1.54 & 0.47 & 0.035 & 5.11 & 0.28 & 0.45 & 4.31 & 12.68 & 7.99 & 9.64 \\
\hline $49-1,16-21$ & 4.60 & 7.14 & 92.88 & 0.64 & 2.82 & 0.62 & 0.042 & 0.79 & 0.28 & 0.13 & 0.92 & 5.74 & 10.65 & 14.53 \\
\hline
\end{tabular}

Note: Analysis by A. F. Zelenova, Research Institute of the Geology of the Arctic, Leningrad. 
(Zhizchenko, 1974) and especially of troughs within these basins.

The depth of our Early Cretaceous sedimentary basin cannot be considered unambiguously. The absence of evidence for benthic photosynthetic organisms (such as algae) and of wave action on homogeneous silt-clayey sediments with preserved finely laminated textures is indicative of a depth not less than 300 meters. A rather good preservation of foraminiferal tests (Figure 5), presence of coccoliths and thin-shelled pelecypods, though not abundant, suggest moderate depths (above the lysocline).

The nature of the sediments implies a near-shore setting and possibly near-deltaic sedimentary conditions. A considerable amount of kaolinite in the clays, a high content of insoluble residue, iron hydroxide in fixed compounds, predominance of higher plant remains in dispersed organic matter, and the absence of hydrobionts typical of deep water basins is evidence for a nearby source area. An unstable salinity regime and periodic freshening of a basin are also indicative of nearby land, namely, the influx of fresh waters. Rivers seem to have been the main routes for a terrigenous material transport into the basin.

The deposits accumulated mainly as the result of sediment removal from land. The source area consisted of sedimentary rocks as evidenced by ideally rounded mineral fragments.

Our data are not sufficient to make definite conclusions about the nature of this Early Cretaceous sedimentary basin. It is possible, however, to assume that it was moderately deep, partly isolated, and generally stagnant with variable salinity and oxidizing-reducing conditions.

The fluctuation of oxidizing-reducing conditions influenced the diagenetic processes.

A diagenetic change of dispersed organic matter, i.e., fusainization and intense humification followed by concentration of humic acids, indicates oxidizing conditions. This is confirmed by the higher content of ferrous iron as compared to ferric iron based on the chemical analysis of the sediments and their low pyrite content. Diagenetic alteration of biotite into hydromica minerals when a considerable amount of iron hydroxide is released also indicates oxidizing conditions. The periods of reducing condition are reflected in the presence of siderite in numerous rhythmic layers of light clays.

The present amount of illite seems to be the result of diagenetic transformation. A part of the primary montmorillonite graded into illite through a mixed-layered mineral phase.

The diagenetic transformation of the Lower Cretaceous sediments reached the first katagenesis stage, if judged from the brown-coal stage $\left(\mathrm{B}_{3}\right)$ of carbonification of dispersed organic matter.

\section{ACKNOWLEDGMENTS}

Thanks are extended to Dr. T. N. Gorbachik (the University of Moscow) for planktonic foraminifer determination and to Dr. T. E. Baranova (Research Petroleum Institute, Leningrad) for the summary of luminescent-microscopic analysis. The authors are indebted to Dr. N. N. Lapina who kindly reviewed the manuscript and provided expert advice.

TABLE 6 - Continued

\begin{tabular}{|c|c|c|c|c|c|c|c|c|c|c|c|}
\hline \multicolumn{6}{|c|}{ mmole } & \multicolumn{6}{|c|}{ Content (\%) } \\
\hline 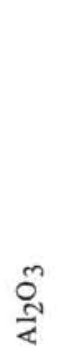 & 일 & 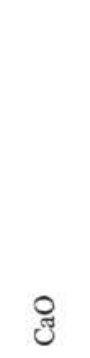 & $\stackrel{8}{\stackrel{8}{\Sigma}}$ & @̊ & $\delta$ & 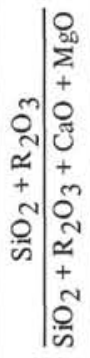 & 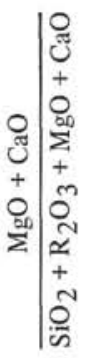 & 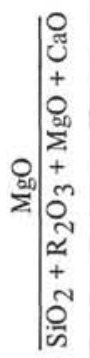 & 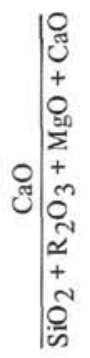 & 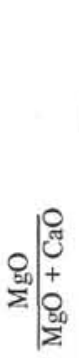 & 일|일 \\
\hline 3.92 & 1.07 & 13.37 & 9.42 & 0.75 & 22.04 & 61.3 & 38.7 & 16.0 & 22.7 & 41.3 & 11.4 \\
\hline 6.57 & 0.63 & 10.16 & 3.97 & 1.50 & 14.09 & 67.3 & 32.7 & 9.2 & 23.5 & 28.1 & 15.9 \\
\hline 5.98 & 0.71 & 7.67 & 5.70 & 1.25 & 14.09 & 70.7 & 29.3 & 12.5 & 16.8 & 42.6 & 12.5 \\
\hline 4.12 & 0.72 & 24.07 & 8.68 & 1.62 & 32.72 & 50.3 & 49.7 & 13.2 & 36.5 & 26.5 & 8.3 \\
\hline 4.81 & 0.49 & 8.38 & 3.47 & 1.25 & 11.82 & 66.6 & 33.4 & 9.8 & 23.6 & 29.3 & 14.1 \\
\hline 4.61 & 0.49 & 91.12 & 6.94 & 5.62 & 97.93 & 18.5 & 81.5 & 5.8 & 75.7 & 7.1 & 7.1 \\
\hline 6.08 & 0.59 & 14.09 & 6.94 & 1.62 & 20.90 & 59.8 & 40.2 & 13.3 & 26.9 & 33.0 & 8.5 \\
\hline
\end{tabular}


TABLE 7

Analyses of Dispersed Organic Matter (DOM) From "Open" and "Closed" Pores

\begin{tabular}{|c|c|c|c|c|c|c|c|c|c|c|c|c|c|c|c|c|c|}
\hline \multirow{3}{*}{ 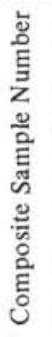 } & \multirow[b]{3}{*}{ 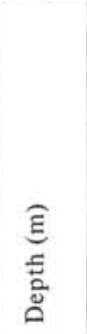 } & \multirow[b]{3}{*}{$\bar{z}$} & \multirow[b]{3}{*}{$\begin{array}{l}\vec{y} \\
0 \\
0 \\
0 \\
0\end{array}$} & \multicolumn{8}{|c|}{ Content (\%) of Whole Rock } & \multirow{3}{*}{ 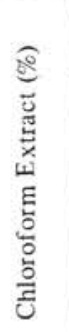 } & \multicolumn{5}{|c|}{$\begin{array}{c}\text { Group Composition (\%) } \\
\text { of Total DOM }\end{array}$} \\
\hline & & & & \multirow[b]{2}{*}{$\begin{array}{l}\text { U. } \\
\text { 总 }\end{array}$} & \multirow[b]{2}{*}{ ల్ల } & \multirow[b]{2}{*}{ ن } & \multirow[b]{2}{*}{$\sum_{0}$} & \multicolumn{3}{|c|}{ Extract } & \multirow[b]{2}{*}{ 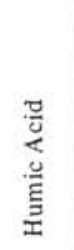 } & & \multirow[b]{2}{*}{$\begin{array}{l}\text { E } \\
\frac{0}{0} \\
\frac{0}{\tilde{c}}\end{array}$} & \multirow[b]{2}{*}{ 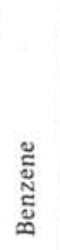 } & \multirow[b]{2}{*}{ 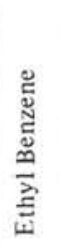 } & \multirow[b]{2}{*}{$\begin{array}{l}\text { 总 } \\
\stackrel{0}{0} \\
\text { 总 }\end{array}$} & \multirow[b]{2}{*}{ 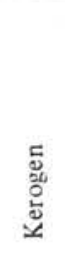 } \\
\hline & & & & & & & & 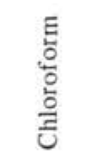 & 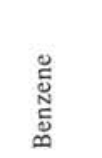 & 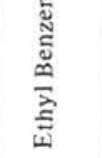 & & & & & & & \\
\hline 7 & $\begin{array}{l}1310- \\
1330\end{array}$ & - & $\begin{array}{l}\text { Open } \\
\text { Closed }\end{array}$ & 0.27 & 2.25 & 0.79 & 1.03 & $\begin{array}{l}0.0201 \\
0.0136\end{array}$ & 0.0126 & 0.0072 & 0.35 & 1.48 & 3.3 & 1.2 & 0.7 & 34.0 & 60.8 \\
\hline 8 & $\begin{array}{l}1440- \\
1453\end{array}$ & 1.680 & $\begin{array}{l}\text { Open } \\
\text { Closed }\end{array}$ & 0.44 & 3.67 & 0.88 & 1.14 & $\begin{array}{l}0.0179 \\
0.0178\end{array}$ & 0.0142 & 0.0051 & 0.45 & 1.01 & 3.1 & 1.2 & 0.4 & 39.5 & 55.8 \\
\hline
\end{tabular}

Note: Recount coefficient of Org. C to DOM =1.3; analysis by I.S. Kozlova and I. E. Popova, Research Institute of the Geology of the Arctic, Leningrad.

TABLE 8

Distribution of $n$-Alkanes

\begin{tabular}{|c|c|c|c|c|c|c|c|c|c|c|c|}
\hline \multirow{2}{*}{$\begin{array}{l}\text { Composite } \\
\text { Sample } \\
\text { Number }\end{array}$} & \multirow[b]{2}{*}{ Porosity } & \multicolumn{2}{|c|}{ DOM $(\%)$} & \multirow{2}{*}{$\begin{array}{l}\text { Me-Nf, } \\
\% \text { of } \\
\text { Hydro- } \\
\text { carbons }\end{array}$} & \multicolumn{6}{|c|}{ Distribution of $n$-Alanes ( $\%$ of Total) } & \multirow[b]{2}{*}{ CPI } \\
\hline & & carbons & $\mathrm{Me}-\mathrm{Nf}$ & & $\mathrm{C}_{14-17}$ & $\mathrm{C}_{18-24}$ & $\mathrm{C}_{25-28}$ & $\mathrm{C}_{29-35}$ & $C_{14-22}$ & $\mathrm{C}_{23-25}$ & \\
\hline \multirow{2}{*}{7} & Open & 0.24 & 0.14 & 57.9 & 1.3 & 22.4 & 49.6 & 26.7 & 9.6 & 90.4 & 2.45 \\
\hline & Closed & 0.55 & 0.29 & 53.2 & 6.2 & 82.3 & 11.5 & - & 78.3 & 21.7 & 1.34 \\
\hline \multirow{2}{*}{8} & Open & 0.35 & 0.20 & 57.5 & 3.3 & 29.4 & 50.5 & 16.8 & 18.2 & 81.8 & 3.71 \\
\hline & Closed & 0.55 & 0.40 & 72.4 & 3.4 & 80.1 & 14.0 & 2.5 & 72.0 & 28.0 & 1.42 \\
\hline
\end{tabular}

Note: Analysis by Yu. S. Schelovanov, VNIGRI, Leningrad.

TABLE 9

Level Valuation of Dispersed Organic Matter Diagenetic Anaerobic Transformations

\begin{tabular}{|c|c|c|c|c|c|c|c|c|c|c|c|c|c|c|c|c|}
\hline 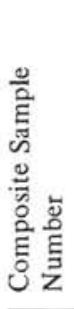 & $\begin{array}{l}\widehat{8} \\
0 \\
0 \\
0 \\
0\end{array}$ & 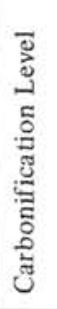 & 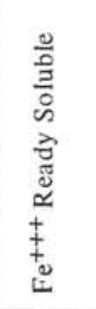 & 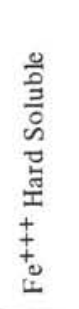 & 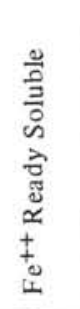 & 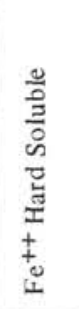 & 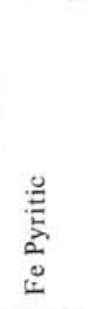 & 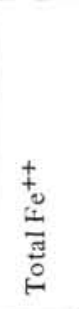 & 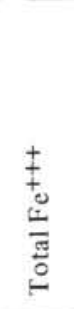 & 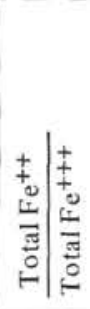 & 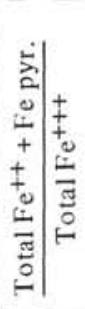 & 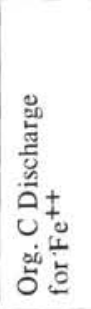 & 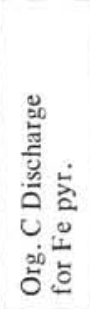 & 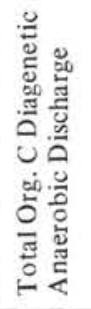 & 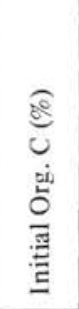 & 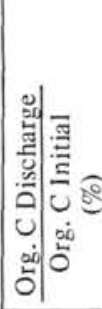 \\
\hline 7 & 0.79 & - & 0.01 & 1.28 & 0.10 & 0.29 & 0.015 & 0.39 & 1.29 & 0.30 & 0.35 & 0.021 & 0.012 & 0.033 & 0.82 & 4.02 \\
\hline 8 & 0.88 & $B_{3}$ & absent & 1.29 & 0.14 & 0.29 & 0.014 & 0.43 & 1.29 & 0.33 & 0.34 & 0.023 & 0.011 & 0.034 & 0.91 & 3.74 \\
\hline
\end{tabular}

TABLE 10

Comparative Analyses of Bitumoids From "Open" and "Closed" Pores

\begin{tabular}{|c|c|c|c|c|c|c|c|c|c|c|c|c|c|c|c|c|c|}
\hline \multirow{2}{*}{ 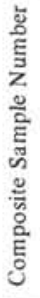 } & \multirow[b]{2}{*}{$\begin{array}{l}\hat{8} \\
\frac{8}{0} \\
0\end{array}$} & \multirow[b]{2}{*}{$\begin{array}{l}\frac{3}{n} \\
0 \\
0 \\
0\end{array}$} & \multicolumn{3}{|c|}{ Elements $(\%)$} & \multirow[b]{2}{*}{$\begin{array}{l}\mathrm{C} \\
\mathrm{H}\end{array}$} & \multirow[b]{2}{*}{$\begin{array}{l}\mathrm{H} \\
\mathrm{C}\end{array}$} & \multicolumn{3}{|c|}{$\begin{array}{c}\text { Group Composition } \\
(\%)\end{array}$} & \multicolumn{2}{|c|}{$\begin{array}{c}\text { Hydro- } \\
\text { carbons (\%) }\end{array}$} & \multirow[b]{2}{*}{ 范文 } & \multicolumn{2}{|c|}{ DOM $(\%)$} & \multirow{2}{*}{ 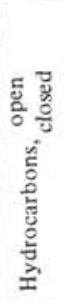 } & \multirow[b]{2}{*}{ 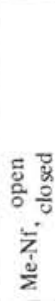 } \\
\hline & & & C & $\mathrm{H}$ & $\begin{array}{l}n \\
+ \\
z \\
+ \\
0\end{array}$ & & & 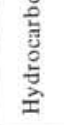 & $\stackrel{\mathscr{E}}{\check{2}}$ & 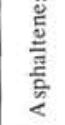 & $\begin{array}{l}\bar{z} \\
\bar{\nu}\end{array}$ & Ar & & 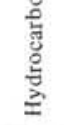 & 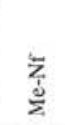 & & \\
\hline 7 & 1.03 & $\begin{array}{l}\text { Open } \\
\text { Closed }\end{array}$ & $\begin{array}{l}70.9 \\
79.5\end{array}$ & $\begin{array}{r}9.6 \\
11.7\end{array}$ & $\begin{array}{r}19.5 \\
8.8\end{array}$ & $\begin{array}{l}7.4 \\
6.8\end{array}$ & $\begin{array}{l}1.62 \\
1.77\end{array}$ & $\begin{array}{l}12.6 \\
42.6\end{array}$ & $\begin{array}{r}11.3 \\
6.6\end{array}$ & $\begin{array}{l}75.3 \\
50.8\end{array}$ & $\begin{array}{l}57.9 \\
53.2\end{array}$ & $\begin{array}{l}42.1 \\
46.8\end{array}$ & $\begin{array}{l}1.37 \\
1.14\end{array}$ & $\begin{array}{l}0.24 \\
0.55\end{array}$ & $\begin{array}{l}0.14 \\
0.29\end{array}$ & 0.4 & 0.5 \\
\hline 8 & 1.14 & $\begin{array}{l}\text { Open } \\
\text { Closed }\end{array}$ & $\begin{array}{l}72.4 \\
79.2\end{array}$ & $\begin{array}{r}9.7 \\
11.6\end{array}$ & $\begin{array}{r}17.9 \\
9.2\end{array}$ & $\begin{array}{l}7.5 \\
6.8\end{array}$ & $\begin{array}{l}1.61 \\
1.76\end{array}$ & $\begin{array}{l}22.1 \\
34.4\end{array}$ & $\begin{array}{l}10.8 \\
19.6\end{array}$ & $\begin{array}{l}67.1 \\
44.0\end{array}$ & $\begin{array}{l}57.5 \\
72.4\end{array}$ & $\begin{array}{l}42.5 \\
27.6\end{array}$ & $\begin{array}{l}1.85 \\
2.62\end{array}$ & $\begin{array}{l}0.85 \\
0.54\end{array}$ & $\begin{array}{l}0.20 \\
0.40\end{array}$ & 0.6 & 0.5 \\
\hline
\end{tabular}

Note: Analysis by 1.S. Kozlova, Research Institute of the Geology of the Arctic, Leningrad. 


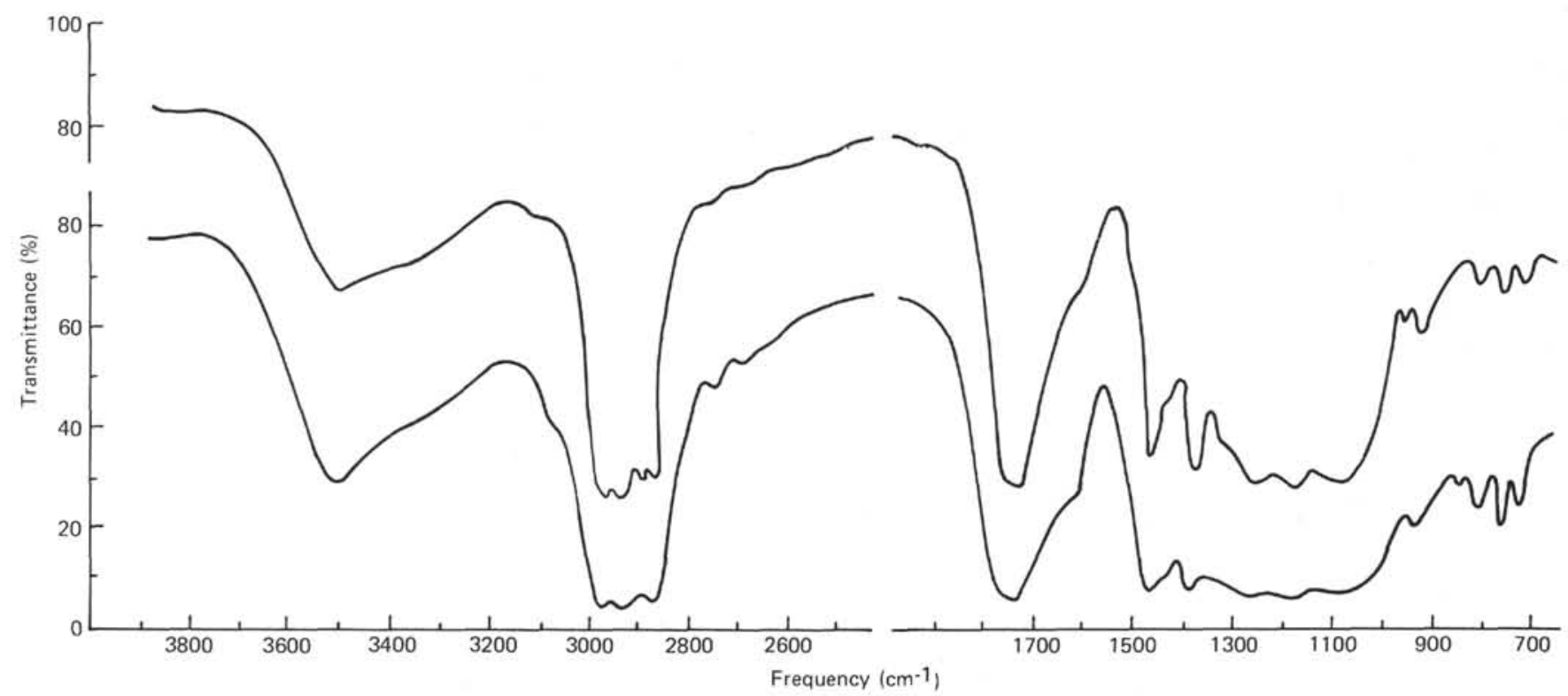

Figure 3. IR spectra of the chloroform extracts of composite samples from Hole $397 \mathrm{~A}$.
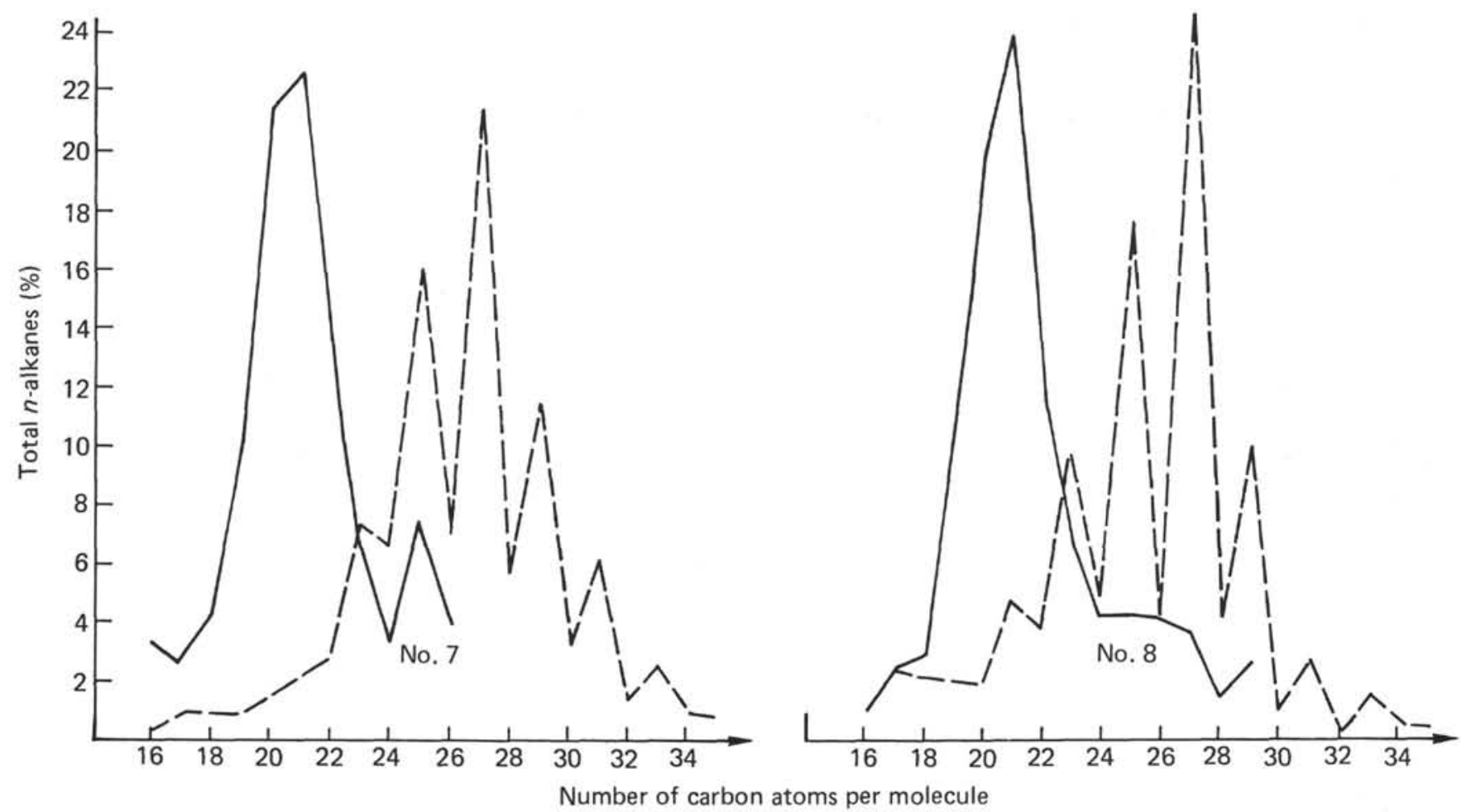

Note: $f=$ open pores, $/$ = closed pores

Figure 4. Distribution of $\mathrm{n}$-alkanes in two combined samples (7 and 8), Hole $397 \mathrm{~A}$. 


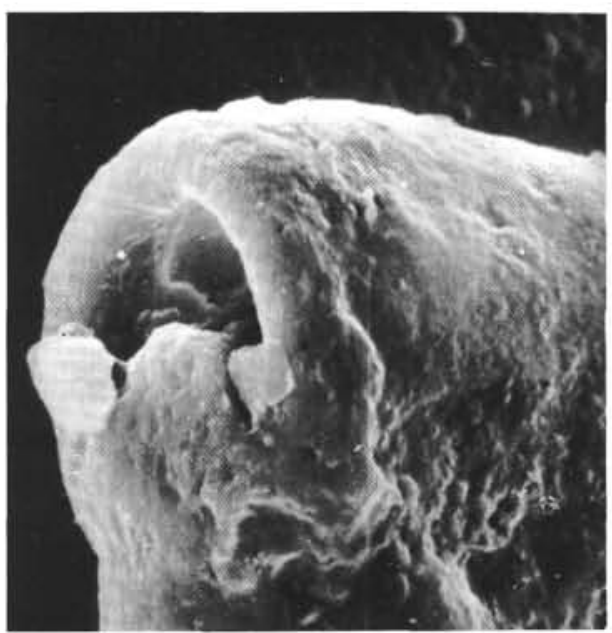

Figure 5. Scanning electron micrograph of the foraminiferal test Pseudosigmoilina (?) ex gr. infravalanginiana (Bartenstein).

\section{REFERENCES}

Antonova, Z. A., Shmygina, T. A., Gnedina, A. G., and Kalugina, O. M., 1964. Neocomian and Aptian foraminifers of the Pshekhaubin region (the North-western Caucasus) (in Russian), Trudy krasnodarskogo filiala VNIINEFTGAS, vypusk 12, p. 3-72.

Bartenstein, H., Bettenstaedt, F., and Bolli, H., 1957. Die Foraminiferen der Uterkreide von Trinidad, B. W. 1, Ecolog. Geol. Helv., v. 50, p. 5-67.

Fitzgerald, M., 1970. Applied spectroscopy, v. 24, p. 106.

Fuchs, W., 1971. Eine alpine Foraminiferen fauna des tieferen Mittel-Barreme aus den Drusbergschichten vom Ranzenberg bei Hohenems in Vorarlberg, Abh. Geol. Bund., v. 27 , p. 49.
Manskaya, S. M., Drozdova, T. V., 1964. Geochemistry of organic matter (in Russian): Moskva (Izdatelstvo Nauka), p. 69-87.

Strakhov, N. M. and Zalmanzon, E. R., 1955. Distribution of authigenic mineral forms of $\mathrm{Fe}$ in sedimentary rocks, and its application to lighology (in Russian), Izvestiya Akademii Nauk SSR, ser. geol., p. 35.

Uspensky, V. A., Rodionova, K. F., Gorskaya, A. I., and Shishkova, A. P., 1966. Textbook on analyses of rocks for bitumenes and dispersed organic matter (in Russian), Trudy VNIGRI and VNIGNI: Leningrad (Izdatelstvo Nedra), p. 95-105.

Zhizchenko, B. P., 1974. Methods of paleogeographic research in petroleum-gas bearing regions (in Russian): Moskva (Izdalestvo Nedra), p. 376. 



\section{PLATE 1}

(Hole 397A)

Figure 1 Ammodiscus cretaceous (Reuss), Sample 397A-47-3, $49-52 \mathrm{~cm}$ $(50 \times)$.

Figures 2, 3, Pseudosigmolina(?) ex gr. infravalanginiana $(200 \times$ and $150 \times)$ P1 9 (Bartenstein).

2 and 9. Samples 397A-49-2, 76-80 cm.

3. Sample 397A-50-1, 37-41 cm $(150 \times)$ P1.

Figure 4 Quinqueloculina(?) horrida Antonova, Sample 397A-50-1, 37$41 \mathrm{~cm}(90 \times)$.

Figures 5, 6, 8 Pseudosigmoilina(?) ex gr. infravalanginiana (Bartenstein).

11

5, 6. Sample 397A-50-1, 37-41 cm $(300 \times)$ P1.

8. Sample 397A-52-2, 26-31 cm $(300 \times)$.

11. Sample $397 \mathrm{~A}-50-1,37-41 \mathrm{~cm}(500 \times)$.

Figure 7 Saccammina sp., Sample 397A-47-3, 49-52 cm $(50 \times)$.

Figure $10 \quad$ Quinqueloculina sp., Sample 397A-38-1, 76-78 cm $(150 \times)$.

Figures 12, 13 Lenticulina nodosa (Reuss), Sample 397A-47-4, 30-33 cm (120×)

Figure $14 \quad$ Lenticulina sp., Sample 397A-47-4, 30-33 cm $(100 \times)$.

Figure 15 Vaginulinopsis sp., Sample 397A-50-4, 69-73 cm $(90 \times)$.

Figure 16 Lingulina sp., Sample 397A-50-1, 37-41 cm $(120 \times)$.

Figure 17 Lenticulina sp., Sample 397A-51-6, 78-82 cm $(90 \times)$.

Figure 18 Planularia bradyana (Chapman), Sample 397A-50-2, 111-115 cm $(90 \times)$.

Figures 19, 20 Lenticulina sp., Sample 397A-47-4, 30-36 cm $(90 \times)$.

Figures 21, 22 Lenticulina sp. 2 Bartenstein, Bettensteadt and Bolli. Sample 25,26 397 A-47-4, 30-33 cm $(90 \times)$.

Figures 23, 24 Lenticulina roemeri (Reuss), Sample 397A-47-4, 30-33 cm $(90 \times)$.

Figures 27, 28 Hoeglundina umboornata (Antonova), Sample 397A-47-4, 30-33 $\mathrm{cm}(180 \times)$.

Figure 29 Hoeglundina cf. laticostata (Antonova), Sample 397A-51-6, 78-82 $\mathrm{cm}(160 \times)$.

Figure 30 "Globigerina" triangulata (Antonova), Sample 397A-47-4, 30-33 $\mathrm{cm}(180 \times)$. 


\section{PLATE 1}
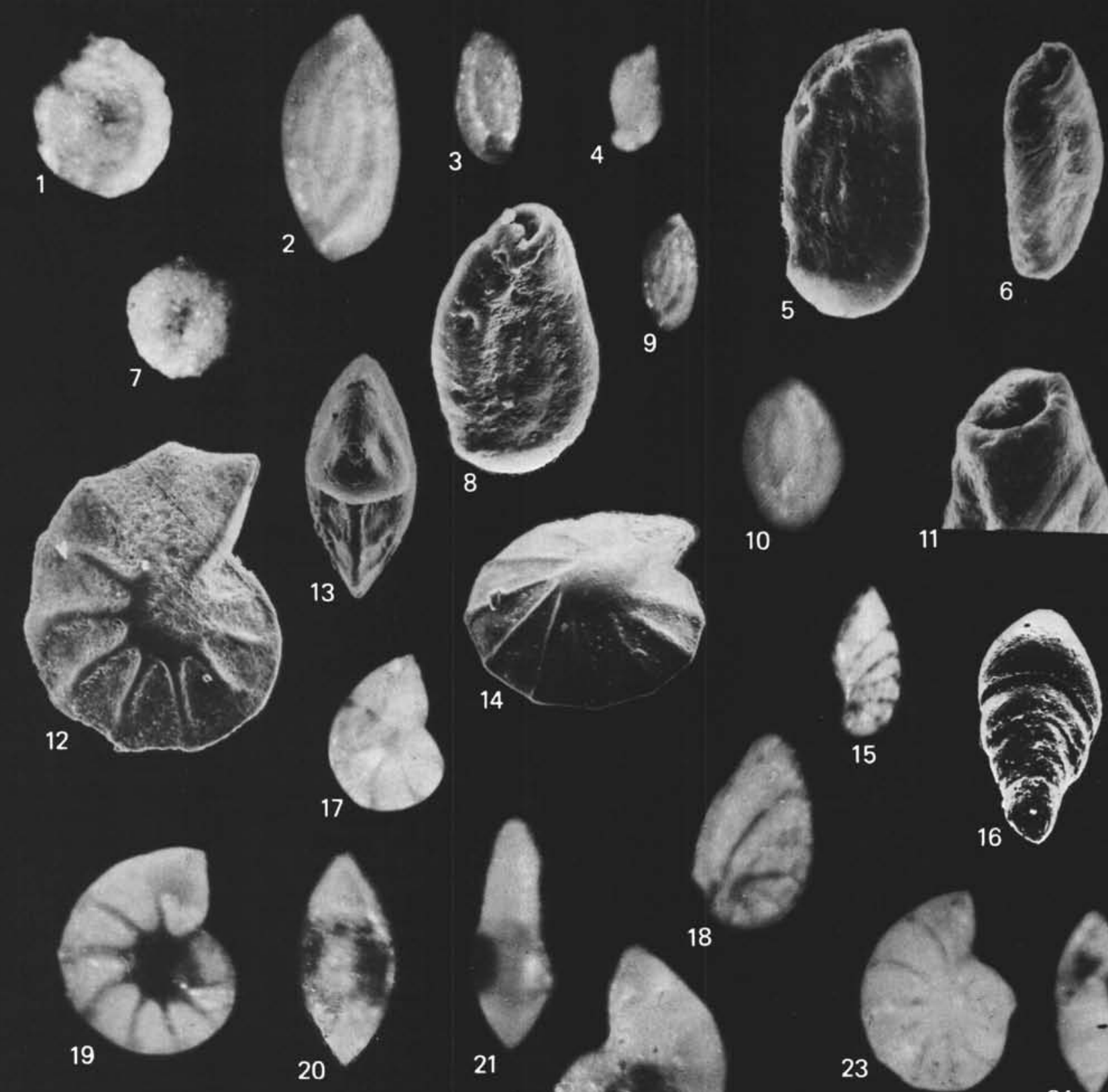

9
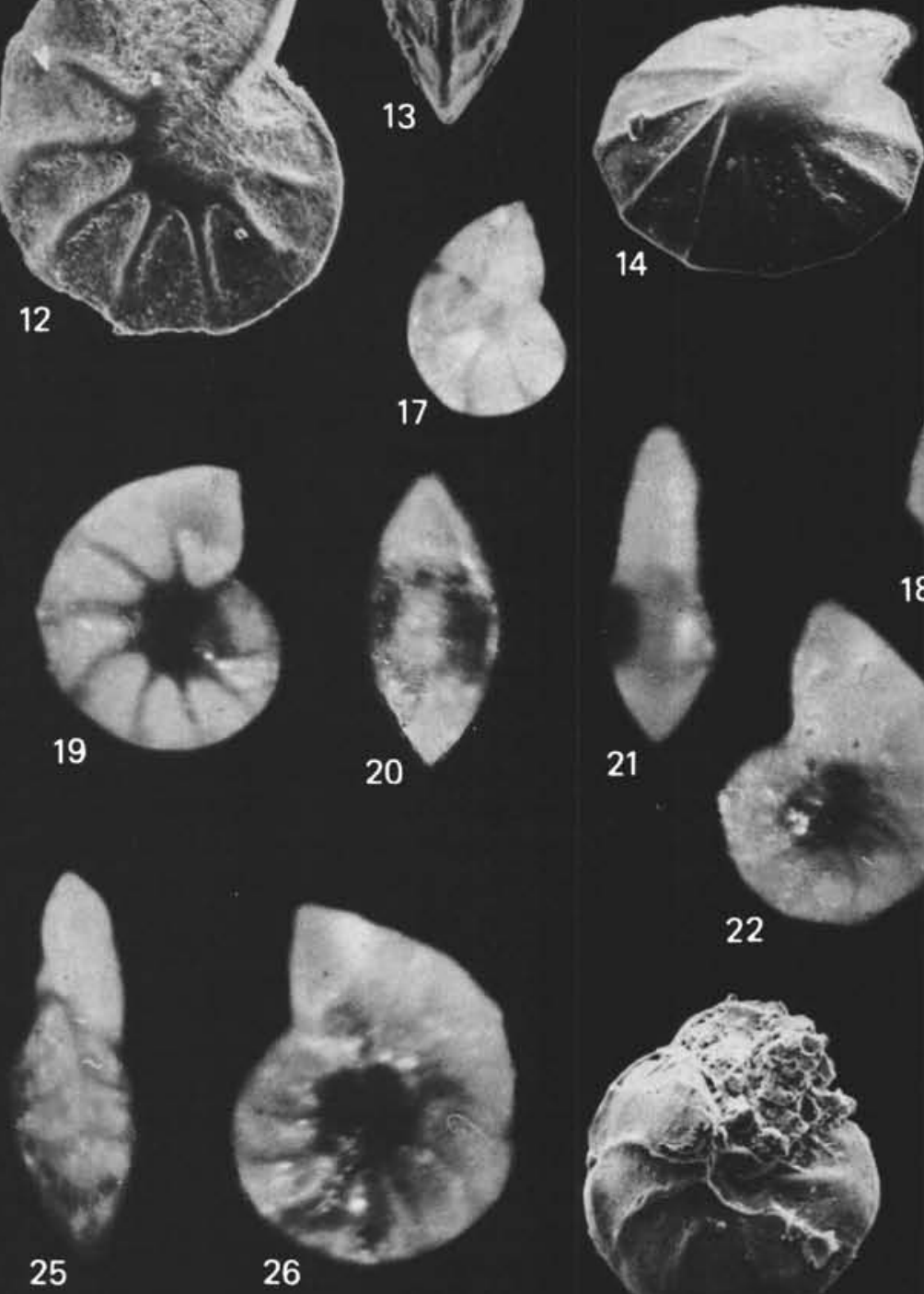

10
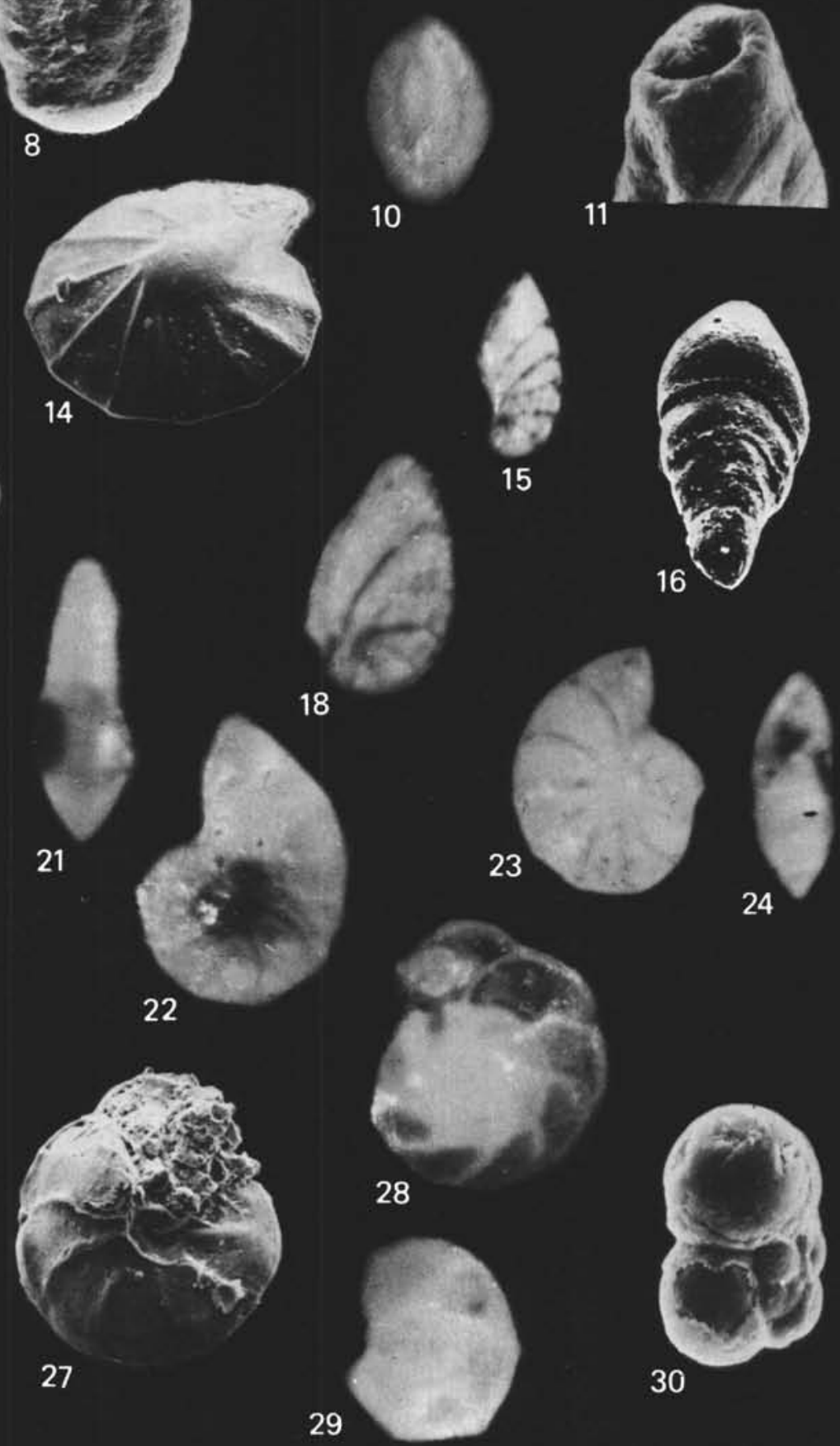


\section{APPENDIX A}

Methods of Dispersed Organic Matter (DOM) Investigation

Two samples ( 100 to 150 each), grouped on the basis of their lithologic similarity, were used to study DOM.

A level of carbonification changes of organic matter was estimated using the refractive index of vitrinite inclusions in rocks on refractometer IRF-22 in immersion; the range of refractive indexes studied was 1.680 to 1.750 .

Luminescent-microscopic studies of DOM distribution in rocks were carried out on LM-2 and LUMAM-R-1 in ultraviolet light from a source DRSh-250 with excitation filter UFS-3 and suppression filter GS-3; magnification was 50 and 100.

Bitumoid analysis of DOM used techniques accepted in the USSR (Uspensky et al., 1966). Determination of $\mathrm{C}_{\text {org }}$, followed the method given by Knop.

A comparative study of bitumoids in "open" and "closed" pores was used for more detailed investigation soluble components. Parts of rocks accessible to extract were called "open" pores, whereas those opened by disintegration were called "closed." This method although conditional, allows for more precise determination of hydrocarbon redistribution and limits initial migration. The successive extraction of DOM fractions soluble in chloroform and alcohol-benzol $(1: 2)$ was carried out at about $80^{\circ} \mathrm{C}$ under the same conditions first for an unbroken sample and then for rocks ground to $\leq 60$ mesh.

After extraction, the remaining rock was treated by 0.5 per cent $\mathrm{NaOH}$ five times (until the solution became colorless). So-called humic acids then were precipitated from a fraction soluble $\mathrm{NaOH}$ with acidification by $\mathrm{HCl}$ up to $\mathrm{pH}=2$. The humic acids were used for further investigation. Kerogen was obtained through treatment by $\mathrm{HCl}$ and $\mathrm{HF}$.

The extracted bitumoids, after topping of a solvent and being dried under vacuum at $40^{\circ} \mathrm{C}$, were subjected to further study. Elementary composition was determined on a $\mathrm{CH}$ analyzer by combustion to calculate oxygen content by difference.

A study of absorption IR Spectra of bitumoids was performed on IR-20.

The analysis of group composition and hydrocarbon composition followed the micromethod of D. K. Zhestkov (Uspensky et al., 1966).

The distribution of $n$-alkanes was determined within the methanenaphthen hydrocarbon fraction. The $n$-alkanes separation was made by LHM-8MD chromatograph with a column $2 \mathrm{~m} \times 1 \mathrm{~mm}$ filled by 5 per cent SE- 30 on chromaton $\mathrm{N}$. The speed of the gas carrier (helium) was $20 \mathrm{ml}$ per min. We used linear programming of temperature and identified chromatograms against an inner standard.

Ultraphotospectrometry on a two-rayed Perkin-Elmer unit (model 402 ; range 220 to $850 \mathrm{~m}$ ) was used to determine distribution of nuclear aromatic structures in the hydrocarbon fractions. Isooctan was used as a solvent in the range of hydrocarbon concentration from 0.002 to 0.01 grams per liter for a $1.0-\mathrm{cm}$ layer. Percentage of aromatic nuclei was calculated by means of a computer with a reversed matrix (Fitzgerald, 1970).
The individual composition of polycyclic aromatic hydrocarbons was determined by means of paper chromatography with a subsequent identification of extracted hydrocarbons on ISP-51 using quasilinear luminescence spectra.

\section{APPENDIX B}

\section{Summary of Luminescent-Microscopic Analysis}

The following analysis was conducted by T. E. Baranova and A. S. Belikova, VNIGRI, Lenigrad.

1) Sample 397 A-36-4, $105-108 \mathrm{~cm}$

Organic matter shows a uniform distribution and is represented by a dispersed mass, plant detritus, and bitumen. The dispersed mass, together with clay minerals, forms a single organomineral assemblage.

The color in ultraviolet light is brown with a greenish shade; structure is subpelletoidal.

Detritus inclusions consist of black, small, and angular fusainized fragments of plant tissue. There are also scarce cuticule fragments having bright yellow luminescence. Bitumen having yellow luminescence shows uniform distribution within a fine-grained rock and apparently is syngenetic. Migratable hydrocarbons, having a bright whitish blue luminescence, are concentrated in most permeable parts of the rock, i.e., in lenses of silty material and as films around individual quartz grains (?). Small rhombic dolomite grains have bright yellow luminescence.

2) Sample $397 \mathrm{~A}-36-4,29-32 \mathrm{~cm}$.

The rock consists of alternating layers of dense clay and small silty partings. Detrital inclusions consist of black fusainized, brown vitrain-like, and yellow small fragments distributed litpar-lit. Bitumen of yellow luminescence is distributed uniformly as films around clastic grains. Hydrocarbons(?) of bluish white luminescence fills the pore space of siltstone bands. All these characteristics imply that bitumens are syngenetic.

3) Sample $397 \mathrm{~A}-50-2,111-115 \mathrm{~cm}$.

Silty clay contains small black plant detritus in the form of angular fragments elongated along bedding, as well as small lenses and branching fragments of plant tissues. Dispersed organic matter forms irregularly distributed yellowish and brown patches in ultraviolet light. Bitumen of yellow luminescence is absorbed by organo-argillaceous assemblage. Hydrocarbons of blue luminescence are concentrated in pore space in siltstone portions and forms films around clastic grains. Hydrocarbons seem to be newly formed in character.

4) Sample $397 \mathrm{~A}-51-3,50-54 \mathrm{~cm}$.

DOM contains small plant fusainized (black) detritus, small vitrain-like fragments, and very small fragments of yellow luminescence. Dispersed hydrocarbon distribution is uniform in a clayey matrix and yellow-brown in ultraviolet light, owing to the presence of bitumen in the pore space. Siltstone lenses are saturated by hydrocarbons of bluish white luminescence.

5) Sample 397A $52-2,26-31 \mathrm{~cm}$.

The character of the organic matter is similar to that of Sample $397 \mathrm{~A}-51-3,50.54 \mathrm{~cm}$.

On the whole, DOM obtained from Hole 397A is considered predominantly organic material formed by higher plants. 